\title{
Bir Tıp Fakültesi Hastanesinde Görev Yapan Hekimlerin COVID-19 Enfeksiyonu ile İlgili Bilgi, Tutum ve Davranışlarının Değerlendirilmesi, Türkiye'den Online Kesitsel Bir Çalışma
}

\section{Evaluation of Covid-19-Related Knowledge, Attitudes and Practices of Physicians Working in A Medical Faculty Hospital: An Online Cross-Sectional Study from Turkey}

\author{
${ }^{1}$ Ayşe Ferdane OĞUZÖNCÜL, ${ }^{1}$ Osman KURT, ${ }^{1}$ Süleyman Erhan DEVECi \\ ${ }^{1}$ Firat University Faculty of Medicine, Department of Public Heatlh, Elazig/ TURKEY \\ Ayşe Ferdane Oğuzöncül: https://orcid.org/0000-0002-9820-9720 \\ Osman Kurt: https://orcid.org/0000-0003-4164-3611 \\ Süleyman Erhan Deveci: https://orcid.org/0000-0002-3041-2327
}

\section{ÖZ}

Amaç: $\mathrm{Bu}$ çalışmada bir tıp fakültesi hastanesinde tıpta uzmanlık eğitimi gören asistan hekimlerin COVID19 ile ilgili bilgi, tutum ve davranışlarının (BTD) değerlendirilmesi amaçlanmıștır.

Materyal ve Metot: Kesitsel tipte olan bu çalışma, bir Üniversite Hastanesinde yapılmıştır. Araştırmanın evrenini bu hastanede Tipta uzmanlık eğitimi gören bütün asistan hekimler oluşturmuştur.

Bulgular: Çalışmaya \% 51,9'u kadın olmak üzere toplamda 264 tıpta uzmanlık öğrencisi olan hekim dâhil edilmiştir. Hekimlerin yaş ortalaması $29,7 \pm 3,5$ olarak bulunmuştur. Katılımcıların \%44,3'ü hastanelerinde yapılan COVID ile ilgili ders ya da seminere katılmıștır. Hekimler en fazla oranda "sık el yıkama", "fiziksel temastan kaçınma", "toplu alanlara girmeme" ve "eve girince önce kıyafet değiştirme" şeklinde bireysel önlem almıştır. Dâhili branşta olan hekimlerin bilgi puanı ortalaması cerrahi branşta olanlardan ( $p=0,001)$, COVID-19 ile ilgili ders/ seminere katılan hekimlerin bilgi puanı katılmayanlardan anlamlı şekilde yüksek bulunmuştur $(\mathrm{p}=0,028)$.

Sonuç: Sonuç olarak hekimlerin tutum ve davranışlarında bazı eksiklikler olduğu görülmüștür. Bilgi anlamında eksikliklerin giderilebilmesi için hekimlere aralıklarla eğitimler planlanabilir.

Anahtar Kelimeler: Bilgi, COVID-19, davranıș, hekim, tutum

\begin{abstract}
Objective: In this study, it was aimed to evaluate COVID-19-related knowledge, attitudes, and practices (KAP) of the assistant physicians who were taking medical specialty training in a medical faculty hospital.

Materials and Methods: We performed this crosssectional study in a university hospital. The universe of the survey was composed of all assistant physicians who were taking medical specialty training in this hospital.

Results: A total of 264 physicians who were taking medical specialty training, involving 137 (51.9\%) women, were included in the study. The mean age of the physicians was found to be $29.7 \pm 3.5$. Besides, $44.3 \%$ of the participants have attended a course or seminar in their hospitals regarding COVID-19. The most frequently taken individual measures by physicians were "frequent handwashing," "avoiding physical contact," "not entering the bulk areas," and "changing clothes first after entering the home." The knowledge score of the physicians in the internal branch and physicians attending a course/seminar regarding COVID-19 was significantly higher than those in the surgical branch $(\mathrm{p}=0.001)$ and those not attending $(\mathrm{p}=0.028)$, respectively.

Conclusions: As a result, we observed some deficiencies in the attitudes and practices of physicians. In order to prevent the lack in terms of information, training can be planned to physicians at regular intervals.

Keywords: Attitude, COVID-19, knowledge, physician, practices
\end{abstract}

\author{
Sorumlu Yazar / Corresponding Author: \\ Osman Kurt \\ Firat University Faculty of Medicine, Department of Public Heatlh, \\ Elazig/ TURKEY \\ Tel: +90 4242370000 - 4685 / 05072078892 \\ Fax: 90 - 3805421387 \\ E-mail: drkurtosman@gmail.com
}

Yayın Bilgisi / Article Info:

Gönderi Tarihi/ Received: 23/06/2020

Kabul Tarihi/ Accepted: 27/08/2020

Online Yayın Tarihi/ Published: 30/06/2020

Atıf / Cited: Oğuzöngül AF et al. Evaluation of Covid-19-Related Knowledge, Attitudes and Practices of Physicians Working in A Medical Faculty Hospital: An Online Cross-Sectional Study from Turkey. Online Türk Sağlık Bilimleri Dergisi 2020;5(3):510-518. doi: 10.26453/otjhs.757041 


\section{INTRODUCTION}

The 2019 coronavirus outbreak affecting the whole world, together with the genetic structure of the virus, was first presented as a summary report on the 24th of January 2020. Zhu et al. isolated the virus in four respiratory samples taken from three cases in that study. They evaluated the effect of that virus on the cells by performing human airway epithelial cell culture. In this case series, where two cases recovered, and one case died due to respiratory failure, Zhu et al. finally named the virus isolated from the cases as $2019-n C o V .{ }^{1}$ Since the researchers detected the virus first on January 13, 2019, its name later has changed as COVID-19.

The epidemic was initially revealed in individuals who were located in the seafood and animal market in Wuhan, China. Then, by transmitting from human to human, it spread to other cities in the province of Hubei, especially Wuhan and other provinces of the People's Republic of China and other countries of the world. The spread of COVID-19 has become unstoppable, and, with the transmission of the virus to more than 100.000 people in 100 countries, COVID-19 has reached the epidemiological criteria required to declare it as a pandemic. ${ }^{2}$ Therefore, COVID-19 disease was announced as a pandemic on the 12th of March $2020 .^{3}$

Coronaviruses are a large family of viruses that can cause disease in animals or humans. In humans, several coronaviruses are known to cause respiratory infections, from the common cold to more severe diseases such as the Middle East Respiratory Syndrome (MERS) and Severe Acute Respiratory Syndrome (SARS) $)^{4}$ Although it has been reported that there may be cases without symptoms, their rate is unknown. In severe cases, pneumonia, severe respiratory failure, kidney failure, and death may develop. ${ }^{4}$

As of April 9, 2020, more than 2.241.778 confirmed cases of COVID-19 and at least 152.551 death have been reported in 212 countries (territories/areas), according to the World Health Organization (WHO). ${ }^{5}$

Healthcare workers, especially physicians, play significant roles in the prevention and treatment of COVID-19 pandemics. Physicians who have to be in close contact with the patient must know every stage of the pandemic process. Their attitudes and practices towards the epidemic are expected to be positive for their and the other individuals' health. We aimed, in this study, to evaluate COVID-19-related knowledge, attitudes, and practices (KAP) of the assistant physicians who were taking medical specialty training in a medical faculty hospital.

\section{MATERIALS AND METHODS}

This descriptive study was conducted between March and April 2020 in Firat University Medical Faculty Hospital of Elazığ that is located in Turkey's Eastern Anatolia region. Ethical approval was obtained for the study from the Ethics Committee of Firat University, Non-Interventional (Date: 13/04/2020 decision no: 2020/06-02 ).

The universe of the study was composed of all assistant physicians (342 persons) who were taking medical specialty training at Firat University Faculty of Medicine. 216 and 126 of those 342, involved in the internal and surgical branch of medicine, respectively. We also aimed to reach the entire universe without selecting a sample. Two hundred sixty-four physicians were accessed (responsiveness rate 77.2\%). The reason for not being able to reach the entire universe was having a high workload of some physicians because of the COVID-19 pandemic.

The questionnaire survey, prepared by the researchers based on the literature, ${ }^{3-5}$ was applied to the involved volunteer individuals via a google form. The reason for using the online method for the survey is that the social isolation rule is applied due to the epidemic. Before starting the survey, the participants were informed that the information received would not be used outside the scientific platform of this study. Besides, necessary explanations were made about the survey and the questions of the questionnaire. Since the questionnaire form was not a scale study, its validity and reliability have not been studied. The questionnaire consisted of sociodemographic characteristics, questions in which KAP about COVID-19 were evaluated. The score range that could be achieved from the scoring done by giving "1 point" to those who know the knowledge questions about COVID-19 correctly and " 0 points" to those who do not know was determined as $0-11$. No such assessment has been made for attitude and practice questions.

Statistical Analysis: We used SPSS 22 (Statistical Package for the Social Sciences, version 22) statistical package program to analyze data. Descriptive values were indicated by number, percentage, mean \pm standard deviation. We performed a normality analysis of measurement data with the KolmogorovSmirnov test. For data fitting the normal distribu- 
tion, whereas Student's t-test was carried out to compare binary groups, the One Way ANOVA test to compare more than two groups. We considered $\mathrm{p}<0.05$ statistically significant in all analyzes.

\section{RESULTS}

A total of 264 physicians who were taking medical specialty training, involving 137 (51.9\%) women and $127(48.1 \%)$ men, were included in the study. The mean age of the physicians was $29.7 \pm 3.5 .134$ $(50.8 \%)$ of the participants were married, and 201 (76.1\%) were working in the internal branch of medicine. While $193(73.1 \%)$ of the physicians were keeping sentry, the median of the number of keeping sentry was found to be $6.9 \pm 2.9$.

The median of assistantship duration of all physicians was shown to be $2.6 \pm 1.2$ years (Table 1 ).

Among the participants, no history of traveling abroad has been found in the past month. However, 22 of the physicians $(8.3 \%)$ had close contact with someone who had traveled abroad in the past month. $32(12.1 \%)$ of the physicians stated that they had a relative or an acquaintance who was diagnosed with COVID-19. Besides, 227 (86.0\%) of those mentioned that they did not have and, $5(1.9 \%)$ mentioned that they were not sure. 93 (35.2\%) of the physicians participating in the study evaluated their knowledge level as "good," 158 (59.8\%) as "intermediate," and $13(4.9 \%)$ as "bad." One hundred seventeen of the participants $(44.3 \%)$ have attended a course or seminar in their hospitals regarding COVID-19. When the physicians were asked about the ways to obtain information about COVID-19, 225 (85.2\%) "websites or social media accounts of professional organizations like the Ministry of Health, World Health Organization (WHO)," 117 (44.3\%) “ informable meetings that were held at institutions," 169 (64.0\%) "scientific articles published about COVID19 ", 174 (65.9\%) "social media accounts such as Instagram, Facebook, Twitter, Whatsapp" and 105 (39.8\%) answered such as from "Television and radio programs" (Figure 1).

Of 342 physicians, $168(63.6 \%)$ questioned the history of high fever and travel abroad in the last month of the patients. $75(28.4 \%)$ physicians notified that they would hesitate to treat COVID-19 patients who came to the examination after recovery, and 119 (45.1\%) they would not hesitate. $206(78.0 \%)$ of participants thought that after the COVID-19 pandemic, they would be more careful in their standard measures regarding contamination in the patients. $247(93.6 \%)$ of 342 physicians who were taking medical specialty training stated that there was a change in their handwashing behavior after the epidemic. The most frequently taken individual measures by physicians were "frequent handwashing," "avoiding physical contact (handshakes, kisses, etc.)," "not entering the bulk areas," and "changing clothes first after entering the home." However, only $4(1.5 \%)$ declared that they did not take any additional measures (Table 2)

The mean knowledge score of the participants was detected to be $8.7 \pm 1.4$. The knowledge score of the physicians in the internal branch and physicians attending a course/seminar regarding COVID-19 was significantly higher than those in the surgical branch $(p=0,001)$ and those not attending $(p=0.028)$, respectively. We found a significant correlation between knowledge score and knowledge level related to COVID-19 $(\mathrm{p}<0.001)$, and this striking difference emerged between all groups (Table 3 ).

\section{DISCUSSION AND CONCLUSION}

As far as we know, our study is the first one in Turkey, examining the $\mathrm{KAB}$ of health care workers, especially physicians, about COVID-19. In this survey, none of the participants had a history of traveling abroad in the last month. However, $8.3 \%$ of them have had close contact with someone who has been traveling abroad in the last month. In the study conducted towards the public in Thailand, $0.6 \%$ of the participants had a travel history to Wuhan city of China in the last three months, and $13.3 \%$ had close contact with someone who arrived from this city. ${ }^{6}$

Participants most frequently used the websites or social media accounts of professional organizations such as the Ministry of Health, WHO (85.2\%). In a study carried out for the public in Iran, it was reported that the participants received information about the COVID-19 epidemic (82.9\%) most commonly from social media and the internet. ${ }^{7}$ Deng et al. stated that $79 \%$ of the participants received information from hospital guidelines and 49\% from the World Health Organization (WHO) official website, in their study regarding Severe acute respiratory syndrome (SARS). ${ }^{8}$ The presence of such differences in the literature about information sources may be related to the universe of our study. Physicians are more inclined to get their information directly from the Ministry of Health or WHO due to their profession. In our study, $83.3 \%$ of physicians used face masks. In comparison, 91.3\% have not entered bulk areas. In the study performed in Iran, $75 \%$ of the participants wore masks when they went out. ${ }^{7}$ Tice et al. 
demonstrated that $57 \%$ of physicians among healthcare workers wore masks in their study about SARS. ${ }^{9}$ Also, in the study conducted by Deng et al., $67 \%$ of physicians wore masks. ${ }^{8}$ Elamin et al. indicated that $83.3 \%$ of healthcare workers wore masks in their research related to Middle East Respiratory Syndrome-coronavirus (MERS-CoV) infection. ${ }^{10}$ Our study findings have some differences when compared with literature data. That may result from the following considerations. Physicians among healthcare workers are in the high-risk group and more susceptible to the transmission of the COVID-19. Therefore, they are more careful in taking individual measures. SARS, MERS, and COVID-19 infections caused by the Coronaviruses have also different infectiousness. The spread of infection for the COVID -19 pandemic is, moreover, more rapid than the epidemic of SARS and MERS. ${ }^{11}$

According to our study results, no significant association was determined between gender and marital status and knowledge level. In the study built by Zhong for Chinese society, the knowledge level of women and married people was significantly higher than men and single people, respectively. ${ }^{12}$ Erfani et al. too reported in their study from Iran that the knowledge level of women and single people was significantly higher than men and married people, respectively. ${ }^{7}$ One study was done in Thailand by Srichan et al., revealed that singles were significantly more knowledgeable than married people. However, there was no significant association between gender and knowledge level. ${ }^{6}$ In their study of MERS infection for healthcare workers, Elamin et al. found no significant association between gender and knowledge level. ${ }^{10}$ We observed similar results in our study, too, when compared with the other studies conducted for healthcare workers in the literature. This situation can be interpreted as gender, and marital status does not affect the level of knowledge, especially in healthcare workers.

In this study, we found no statistically significant association between physicians' status of keeping sentry and knowledge level. However, it was seen that the knowledge level of physicians in the internal branch was significantly higher than those in the surgical branch. Because of the workload and responsibility given to physicians in the internal branch, those tended to be more knowledgeable. Although all physicians were assigned due to the state of emergency, such difference emerged in the knowledge level of physicians is very striking.

At the same time, we have seen the knowledge level of the physicians who attended a course/seminar about COVID-19 in our hospital to be significantly higher than those who did not attend. This situation can be mentioned as an important example of the contribution of education to knowledge.

In conclusion, we observed some deficiencies in the attitudes and practices of physicians. It was found that the knowledge level of the physicians working in the internal branch and attending a course/seminar was higher than those who did not work and attend. In order to prevent the lack in terms of information, training can be planned to physicians at regular intervals. Besides, various information flows can be provided to them with common social media accounts.

There are some limitations and superiorities in our study. In this study, which we primarily aimed to reach the entire universe, $22.8 \%$ of the physicians could not be reached. Our second limitation has resulted from the social distance rule, which we could not perform our study under direct observation. This status may have led to a low participation rate.

Evaluating the KAB of physicians who are fighting at the forefront against the virus and taking responsibility in the high-risk group can be defined as the superiority of our study.

Ethics Committee Approval: Ethical approval was obtained for the study from the Ethics Committee of Frrat University, Non-Interventional (Date: 13/04/2020 decision no: 2020/06-02 ).

Conflict of Interest: No conflict of interest was declared by the authors.

Author Contributions: Concept - AFO ; Supervision SED; Materials -AFO, OK; Data Collection and Processing - AFO, OK; Analysis and Interpretation - AFO, OK; Writing - AFO, OK, SED.

Peer-review: Externally peer-reviewed.

\section{REFERENCES}

1. Zhu N, Zhang D, Wang W, et al. A novel coronavirus from patients with pneumonia in China, 2019. New England Journal of Medicine. 2020;382:727-733.

2. Callaway E. Time to use the p-word? Coronavirus enter dangerous new phase. Nature. 2020;579:12.

3. Chen H, Guo J, Wang C, et al. Clinical characteristics and intrauterine vertical transmission potential of COVID-19 infection in nine pregnant women: a retrospective review of medical records. The Lancet. 2020;395(10226):809-815. 
4. Perlman S, Another Decade, Another Coronavirus. N Engl J Med. 2020;382:760-762.

5. Epidemiological Update: Coronavirus Disease (COVID-19) https://www.paho.org/en/ documents/epidemiological-update-coronavirusdisease-covid19. Erişim tarihi 20 Nisan 2020.

6. Srichan P, Apidechkul T, Tamornpark R, et al. Knowledge, Attitude and Preparedness to Respond to the 2019 Novel Coronavirus (COVID19) Among the Bordered Population of Northern Thailand in the Early Period of the Outbreak: A Cross-Sectional Study. The Lancet. 2020. doi: http://dx.doi.org/10.2139/ssrn.3546046

7. Erfani A, Shahriarirad R, Ranjbar K, Mirahmadizadeh A, Moghadami M. Knowledge, Attitude and Practice toward the Novel Coronavirus (COVID-19) Outbreak: A Population-Based Survey in Iran 2020. Bull World Health Organ. 2020. doi: http://dx.doi.org/10.2471/ BLT.20.256651

8. Deng JF, Olowokure B, Kaydos-Daniels SC, et al. Severe acute respiratory syndrome (SARS): knowledge, attitudes, practices and sources of information among physicians answering a SARS fever hotline service. Public Health. 2006;120(1):15-19.

9. Tice AD, Kishimoto M, Dinh $\mathrm{CH}$, Lam GT, Marineau M. Knowledge of severe acute respiratory syndrome among community physicians, nurses, and emergency medical responders. Prehospital and Disaster Medicine. 2006;21(3):183189.

10. Elamin F. Knowledge, attitude and practices of healthcare providers towards MERS-CoV infection at Makkah hospitals, KSA. International Research Journal of Medicine and Medical Sciences. 2015;3:103-112.

11.Peeri NC, Shrestha N, Rahman MS, et al. The SARS, MERS and novel coronavirus (COVID19) epidemics, the newest and biggest global health threats: what lessons have we learned? International Journal of Epidemiology. 2020;110.

12.Zhong BL, Luo W, Li HM, et al. Knowledge, attitudes, and practices towards COVID-19 among Chinese residents during the rapid rise period of the COVID-19 outbreak: a quick online cross-sectional survey. International Journal of Biological Sciences. 2020;16(10):1745-1752. 
Table 1. Sociodemographic characteristics of physicians included in the study.

\begin{tabular}{|l|l|c|c|}
\hline \multicolumn{2}{|c|}{} & Number & $\%$ \\
\hline Age (Mean \pm SD) & \multicolumn{2}{|c|}{$29.7 \pm 3.5$} \\
\hline \multirow{2}{*}{ Gender } & Female & 137 & 51.9 \\
\cline { 2 - 4 } & Male & 127 & 48.1 \\
\hline \multirow{2}{*}{ Marital Status } & Married & 134 & 50.8 \\
\cline { 2 - 4 } & Single & 130 & 49.2 \\
\hline \multirow{2}{*}{ Branch } & Internal & 201 & 76.1 \\
\cline { 2 - 4 } & Surgical & 63 & 23.9 \\
\hline \multirow{2}{*}{ The status of keeping sentry } & Yes & 193 & 73.1 \\
\cline { 2 - 4 } & No & 71 & 26.9 \\
\hline Assistantship duration (Mean \pm SD) & \multicolumn{2}{|c|}{$2.6 \pm 1.2$} \\
\hline \multicolumn{2}{|l|}{ The number of keeping sentry (Mean \pm SD) } & \multicolumn{2}{|l}{$6 \pm 2.9$} \\
\hline
\end{tabular}


Table 2. Physicians' attitudes and practices about COVID-19.

\begin{tabular}{|c|c|c|}
\hline & Number & $\%$ \\
\hline \multicolumn{3}{|c|}{$\begin{array}{l}\text { Have you questioned patients' history of high fever and travel abroad in the } \\
\text { last month? }\end{array}$} \\
\hline Yes & 168 & 63.6 \\
\hline No & 96 & 36.4 \\
\hline \multicolumn{3}{|c|}{$\begin{array}{l}\text { Would you hesitate to treat COVID-19 patients who came to the examination } \\
\text { after recovery? }\end{array}$} \\
\hline Yes & 75 & 28.4 \\
\hline No & 119 & 45.1 \\
\hline Undecided & 70 & 26.5 \\
\hline \multicolumn{3}{|c|}{$\begin{array}{l}\text { Would you think that after the COVID-19 pandemic. you will be more careful } \\
\text { in your standard measures regarding contamination in the patients? }\end{array}$} \\
\hline Yes & 206 & 78.0 \\
\hline No & 41 & 15.5 \\
\hline Undecided & 17 & 6.4 \\
\hline \multicolumn{3}{|l|}{ Individual measures taken } \\
\hline Wearing gloves & 146 & 55.3 \\
\hline Wearing a face mask & 220 & 83.3 \\
\hline Frequent handwashing & 262 & 99.2 \\
\hline Use of cologne. wet wipes. hand sanitizer & 228 & 86.4 \\
\hline Not entering the bulk areas & 241 & 91.3 \\
\hline Avoiding physical contact (handshakes. kisses. etc.) & 246 & 93.2 \\
\hline Frequent ventilation of the environment & 219 & 83.0 \\
\hline Changing clothes first after entering the home & 239 & 90.5 \\
\hline Taking a shower after entering the home & 182 & 68.9 \\
\hline There is nothing extra I do & 4 & 1.5 \\
\hline
\end{tabular}


Table 3. Comparison of knowledge scores of physicians according to some variables.

\begin{tabular}{|c|c|c|c|c|}
\hline & & \multicolumn{2}{|c|}{$\begin{array}{l}\text { Knowledge } \\
\text { score }\end{array}$} & \multirow[b]{2}{*}{$\mathbf{p}$} \\
\hline & & Mean & SD & \\
\hline \multirow{2}{*}{ Gender } & Female & 8.65 & 1.47 & \multirow[t]{2}{*}{$0.582^{*}$} \\
\hline & Male & 8.75 & 1.42 & \\
\hline \multirow{2}{*}{ Marital status } & Married & 8.80 & 1.35 & \multirow[t]{2}{*}{$0.247^{*}$} \\
\hline & Single & 8.59 & 1.53 & \\
\hline \multirow{2}{*}{ Branch } & Internal & 8.86 & 1.38 & \multirow[t]{2}{*}{$0.001^{*}$} \\
\hline & Surgical & 8.17 & 1.53 & \\
\hline \multirow{2}{*}{ The status of keeping sentry } & Yes & 8.68 & 1.49 & \multirow[t]{2}{*}{$0.736^{*}$} \\
\hline & No & 8.75 & 1.32 & \\
\hline \multirow{3}{*}{$\begin{array}{l}\text { How do you consider your knowledge level related to } \\
\text { COVID-19? }\end{array}$} & Good & 9.19 & 1.05 & \multirow{3}{*}{$\begin{array}{c}<\mathbf{0 . 0 0 1} \\
* * *\end{array}$} \\
\hline & Intermediate & 8.64 & 1.22 & \\
\hline & $\mathrm{Bad}$ & 5.85 & 2.67 & \\
\hline \multirow{2}{*}{$\begin{array}{l}\text { Have you attended a course or seminar in your hospital re- } \\
\text { garding COVID-19? }\end{array}$} & Yes & 8.91 & 1.07 & \multirow[t]{2}{*}{$0.028^{*}$} \\
\hline & No & 8.53 & 1.67 & \\
\hline
\end{tabular}

* Student t-test, ${ }^{* *}$ One Way ANOVA was used for multigroup comparisons. 


\section{Number (\%)}

From websites or social media accounts of professional organizations like the Ministry of Health, World Health Organization (WHO)

From informable meetings that were held at institutions

From scientific articles published about COVID-19

From social media accounts such as Instagram, Facebook, Twitter, Whatsapp

From Television and radio programs
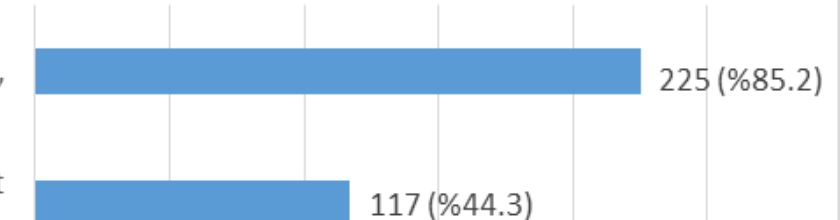

$117(\% 44.3)$

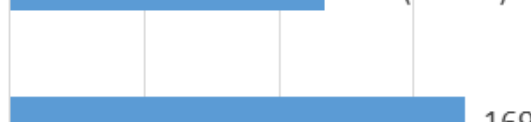

$69(\% 64.0)$

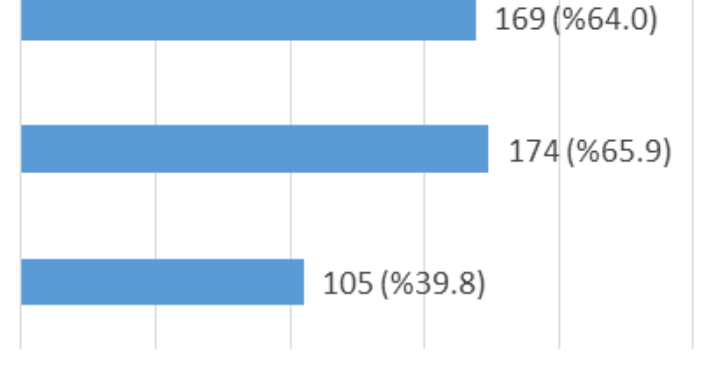

0

50

100

150

200

250

Figure 1. Ways of Physicians to Obtain Information 